\title{
Predicting Effect Implementing the Jigsaw Strategy on the Academic Achievement of Students in Mathematics Classes
}

\author{
Adil Zamil Abed ${ }^{1}$, Sameer Abed Sameer ${ }^{1}$, Munadhil Adil Kasim ${ }^{2,3^{*}}$, Ahamad Tajuddin Othman ${ }^{2}$ \\ ${ }^{1}$ Directorate of Anbar Education, Ministry Of Education of Iraq, IRAQ \\ ${ }^{2}$ School of Educational Studies, Universiti Sains Malaysia, MALAYSIA \\ ${ }^{3}$ Directorate of Maysan Education, Ministry of Eduaction of Iraq, IRAQ

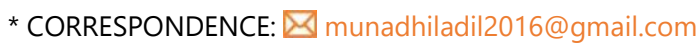

\begin{abstract}
The prime purpose of the current study was to investigate the effect of the predictive power of Jigsaw strategy on low proficient students' proficiency in mathematics and determine the effect of Jigsaw strategy on the mathematics achievement of middle-grades grade-two students. The current study included 80 students who were enrolled in the mathematics lessons in 2017 - 2018 academic year. Of the total sample, forty were included in an experimental group and forty were in control group. The experimental group was given Jigsaw strategy intervention whereas the control group was taught following existing traditional method (teacher-centred). The findings of the study showed that Jigsaw strategy had more positive effect on students' overall mathematics achievement than the control group students. Additionally, the findings also revealed that experimental group students also exhibited positive attitude towards the mathematics lessons. These overall findings have some implications on learning and teaching of mathematics in Iraq context. This study also provides ample evidences that teacher-centered method is obsolete and ineffective especially in teaching mathematics.
\end{abstract}

Keywords: Jigsaw strategy, mathematics class, academic achievement

\section{INTRODUCTION}

Many learners consider Mathematics learning as a challenging task. The scholars also maintain that some learners are born with a "math brain" and some are not, and that high achievement is only available to some learners. Therefore, some learners need to be taught through effective teaching methods in order to learn mathematics in an effective way. Mathematics is one of the main components of the Iraq education curriculum and treated as a compulsory subject. Similarly, parents are also eager to acquaint their children to be adept in Mathematics since it is considered as a key to success in many fields. The main objective of teaching mathematics is to enable students to interact successfully with a variety of social and academic settings. Many studies mathematics achievement is dependent on effective teaching methods (Hu, Xing \& Tu, 2018). Dunlosky et al. (2013) state, that students' achievements lead them to their ultimate goals. To attain academic achievement, learners charge their minds with ideas, knowledge, and experiences that are translated into their behaviour that also help them live in, improve and develop his society appropriately. Kirillov et al ., (2016) indicates that students put untiring efforts for the achievement, regardless of the subject, as they are well-aware of the efforts to be taken to attain academic success. It is discovered that the learner who often excels in mathematics outperforms in other subjects too. So, learning to mathematics is one of the most important strategies learners can accomplish in schools because it is the foundation for all academic

Article History: Received 19 March $2019 \bullet$ Revised 3 May $2019 \bullet$ Accepted 22 September 2019

(C) 2020 by the authors; licensee Modestum Ltd., UK. Open Access terms of the Creative Commons Attribution 4.0 International License (http://creativecommons.org/licenses/by/4.0/) apply. The license permits unrestricted use, distribution, and reproduction in any medium, on the condition that users give exact credit to the original author(s) and the source, provide a link to the Creative Commons license, and indicate if they made any changes. 
endeavors. In recent years, learning and teaching styles and techniques have gradually changed from teachercentered learning styles to modern learner-centered teaching methods. Therefore, studies involving cooperative learning strategy have emerged as an internationally important area of social science studies among researchers.

The cooperative learning strategy is a type of student-centered approaches different from conventional teacher-centred approach (Alzahrani, 2017). Jigsaw strategy is one of the cooperative teaching strategies in which learners learn in small teams being responsible for each other's learning. Jigsaw cooperative learning strategy is one that largely emphasises on facilitating learners with the opportunity to help each other in building and understanding the tasks assigned in the classroom. This style assigns learners to small teams consisting of different skill levels. Each team member strives to be an "Expert" on the assigned classroom materials and then transforming the knowledge to other individuals in the group. In the current study, the researchers accentuated on the effectiveness of cooperative learning strategy i.e., Jigsaw style on students' achievement in mathematics.

\section{LITERATURE REVIEW}

\section{Jigsaw Strategy}

Learning results are the very most essential component of a learning procedure since there is the capability of trainees who are gain from the learning expertise (Peris-Ortiz, Devece-Carañana \& Navarro-Garcia, 2018). Skinner (2016) stated that learning results are the changes that place in the trainees themselves, whether involving psychomotor, affective and cognitive aspects as an outcome of learning activities. Located on the above description can be manufactured that the learning results are the capability of someone after completing a learning and teaching activities through tests outcomes, evaluation/assessment in the type of behavior and the frame of mind that consists of aspects of psychomotor, effective aspects, and cognitive aspects (Fry, Ketteridge \& Marshall, 2008). Social Science is a topic which happens to come from social life in a community that is selected through utilizing social science concepts utilized for the learning function (Akers, 2017). Patten and Newhart (2017) assert that Social Science is a combination of various branches of the sciences, such as history, sociology, economics, geography, culture, politics, and law. Cooperative learning strategy can be translated as something that is performed together and helps with each other in a group (Capar \& Tarim, 2015). Woods and Chen (2010) suggestions cooperative learning is a teaching and learning strategy with a variety of learners as participants of small teams with various levels of ability. Jigsaw is a cooperative learning method kind that is established through Elliot Aronson's. Jigsaw is a kind of cooperative learning strategy in which each individual in a team needs a piece of information to complete the assigned tasks in groups. Hence, it would be a significant strategy to cooperate with the students in the classroom with an intimate atmosphere (Fry, Ketteridge \& Marshall, 2008). Jigsaw style according to Judd, Kennedy and Cropper (2010) is taking a pattern of how to work a saw (zig-zag), it is when the students do a learning and teaching activity in cooperation style with other students to achieve mutual objecatives. In the application of the Jigsaw style, learners are separated from their own teams and included in new teams with the other learners who cooperate with them to learn about the same subject (Sulisworo, Ishafit \& Firdausy, 2016). Such teams are reckoned as "teams of experts". Such teams try to work with other learners and help them understand the subject; they also devise plans about how they can transfer the knowledge of the subject to their colleagues, and prepare a final report. Thus, they return to their own teams with profuse learning and reports they prepare in former teams. is a way for students to share their knowledge and experiences with other groups (Voyles, Bailey \& Durik, 2015). According to Serdyukov (2017), Interest is motivation in a learner or elements that produce a rate of interest effectively, which results in the option of object and activity that is enjoyable, profitable, and will ultimately bring complete satisfaction in itself.

Through this strategy, students must feel themselves more comfortable with their roles. To evaluate the teams can develop the effectiveness of the jigsaw technique by working each learner have a sense of responsibility for their team's performances in the classroom (Aydin \& Biyikli, 2017). In Jigsaw style, each learner prepares a part of the assignment outside the lesson. Later they turn to their teams and peer transforms knowledge to other individuals. Whereas all teams enable to take the selfsame subject, different teams enable to take different parts of it as well. Teams are reorganized to learn the subject in turn (Ronfeldt, Farmer, McQueen \& Grissom, 2015). For this the reason, it is necessary to diagnose the effects of this technique on the academic students' achievement particularly in mathematics classes. In the study, it was also aimed to determine the views of students in the experimental group as well as the impacts of the 
Table 1. The distribution of the sample

\begin{tabular}{lccc}
\hline Group & Control & Experimental & Total \\
\hline No. of the sample & 40 & 40 & 80 \\
\hline
\end{tabular}

Table 2. t-test results for pre-test and attitude scores towards learning English before experiment

\begin{tabular}{|c|c|c|c|c|c|c|c|}
\hline & Groups & $\mathbf{n}$ & $\mathbf{X}$ & sd & df & $\mathbf{T}$ & Sig. \\
\hline Pre-test & $\begin{array}{l}\text { Experimental } \\
\text { Control }\end{array}$ & $\begin{array}{l}40 \\
40\end{array}$ & $\begin{array}{l}12.39 \\
12.48\end{array}$ & $\begin{array}{l}2.07 \\
2.19\end{array}$ & 78 & 0.359 & 0.752 \\
\hline $\begin{array}{l}\text { Academic achievement } \\
\text { before experiment }\end{array}$ & $\begin{array}{l}\text { Experimental } \\
\text { Control }\end{array}$ & $\begin{array}{l}40 \\
40\end{array}$ & $\begin{array}{l}3.82 \\
3.55\end{array}$ & $\begin{array}{l}0.85 \\
0.90\end{array}$ & 78 & 0.385 & 0.689 \\
\hline
\end{tabular}

instructional teacher-centered learning strategy and Jigsaw style on students' academic achievement and their attitudes to mathematics classes.

\section{HYPOTHESES}

The current study aims to test the following hypotheses:

1. There is no significant difference between experimental and control group students' attitudes toward implementing the Jigsaw teaching method in mathematics classes?

2. There is no significant difference between the experimental group and the control group in terms of their pre-post-and retention academic achievement tests scores in mathematics.

\section{METHODOLOGY}

\section{Type of Research}

The current study followed explanatory research design that highlights the relationship between research variables and tests the previously formulated hypothesis (Gray \& Malins, 2016). The current study applied the experimental approach involving two groups: a control group and an experimental group. The experimental group was taught mathematics according to the techniques of Jigsaw style while the control group was taught through the teacher-centered method.

\section{Study Population}

The present study included middle-grades students enrolled in 2017 - 2018 academic year.

\section{Study Sample}

The sample included (80) females divided in two different groups: the experimental group comprised (40) learners whereas the control group included (40) learners. The learners in the both the groups were chosen following random sampling procedure as illustrated in Table 1.

Both the groups exhibited similar proficiency level in their general achievement test in the second term of 2017 - 2018 academic year. This is because classes were originally distributed according to their findings by the school administration beforehand. The learners' age was treated as the confounding variable and controlled in the study. "Pre-test/post-test design with control-experimental group" was applicated in this work. The pre-test was conducted to determine the homogenous groups and the post test was conducted to determine if there was any impact of Jigsaw teaching method on learners' proficiency in mathematics. The treatment lasted for the 8 the weeks. Prior to the administration of the tests, an ethical approval was sought from the concerned school authorities. Additionally, all the participants of the study were assured that the said study would not cause any harm to them in any way. Moreover, they were also assured that they would be informed of the results of the study once it is completed and published online.

\section{RESULT}

To analyse the data, samples independent t-test was performed in the SPSS (version 24) to determine if there was any statistical difference in the written expression achievement scores between the experimental and control group. This test served to establish the homogeneity between the groups on the pre-test. Table 2 displays the results. 
Table 3. t-test results for post-test scores of a section of the academic achievement test

\begin{tabular}{lcccccc}
\hline Groups & $\mathbf{n}$ & $\mathbf{X}$ & $\mathbf{s d}$ & $\mathbf{d f}$ & $\mathbf{t}$ & Sig. \\
\hline Experimental & 40 & 7.56 & 1.24 & 78 & $6.118^{*}$ & 0.001 \\
\hline Control & 40 & 5.89 & 0.96 & & & \\
\hline
\end{tabular}

Significant at the 0.05 level

Table 4. t-test findings for (post-test) scores of the groups

\begin{tabular}{lcccccc}
\hline Groups & $\mathbf{n}$ & $\mathbf{X}$ & $\mathbf{s d}$ & $\mathbf{d f}$ & $\mathbf{t}$ & Sig. \\
\hline Experimental & 40 & 25.85 & 3.48 & 78 & $8.975^{*}$ & 0.001 \\
\hline Control & 40 & 19.35 & 2.89 & & & \\
\hline
\end{tabular}

Significant at the 0.05 level

Table 5. t-test results for delayed posttest scores of the groups

\begin{tabular}{lcccccc}
\hline Groups & $\mathbf{n}$ & $\mathbf{X}$ & $\mathbf{\text { sd }}$ & $\mathbf{d f}$ & $\mathbf{T}$ & Sig. \\
\hline Experimental & 40 & 20.46 & .194 & 78 & 8.976 & 0.001 \\
\hline Control & 40 & 16.87 & .183 & & & \\
\hline
\end{tabular}

Significant at the 0.05 level

Table 6. t-test findings for post- academic achievement

\begin{tabular}{lcccccc}
\hline Groups & $\mathbf{n}$ & $\mathbf{X}$ & $\mathbf{~ s d}$ & $\mathbf{d f}$ & $\mathbf{T}$ & Sig. \\
\hline Experimental & 40 & 7.49 & 0.691 & 78 & $7.367^{*}$ & 0.001 \\
\hline Control & 40 & 5.93 & 0.532 & & & \\
\hline
\end{tabular}

Significant at the 0.05 level

The findings revealed no significant difference between the two groups on the pre-test $[\mathrm{t}(78)=0.359, \mathrm{p}>$ 0.05]. Additionally, both the control and the experimental groups did not also differ in terms of their academic achievement scores on the pre-test $[\mathrm{t}(78)=0.385, \mathrm{p}>0.05]$. These overall findings suggest that the both the groups were homogenous.

Table 3 reveals that the both the groups were significantly different in terms of their academic achievement on the post test.

The results of Table 4 reveal mathematics achievement of the both the groups on the post test. It can be observed that the test scores for the experimental group significantly increased more than the control group students [t(58) $=8.975, \mathrm{p}<0.05]$. These findings imply that the Jigsaw teaching method has a positive impact on students' mathematics proficiency. On the contrary, the teacher-centered group students did not yield satisfactory performance in the mathematics. It can be concluded the complexity in mathematics tasks can be easy for those who work in groups and the leaners who are solely dependent on teachers are likely to face difficulties in comprehending the mathematics.

Table 5 shows the findings of the knowledge retention of the experimental and the control group. The results of the t-test showed that the experimental group obtained higher score than the control group in the delayed post-test $[t(78)=8.976, p<0.05]$. These findings suggest that the Jigsaw strategy has undeniable impact on students' achievement and knowledge retention. Moreover, such findings also suggest that teachercentered teaching is not only ineffective in teaching mathematics but it also ineffective in helping students keep knowledge retention.

The findings depicted in Table 6 show that the learners' score in the experimental group in academic achievement in mathematics was higher than the control group $[t(78)=7.367, p<0.05]$. These findings suggest that the teaching method using Jigsaw approach paves the way for the students to develop mathematics skills effectively. Moreover, students also develop the sense of the importance of working in groups. Hence, the Jigsaw teaching strategy can be incorporated in the classes so as to help students enhance their academic achievement particularly in mathematics classes.

\section{CONCLUSION}

The findings of this study showed that the Jigsaw style had more significant role than the teacher-centered teaching method to develop students' mathematics skills. The current study focused on Jigsaw style and supports Mattingly and VanSickle (1991) and Slavin's (1987) findings that small group of students must be acquainted with the importance cooperative learning to attain academic excellence. The experimental group 
exhibited the significant increase in their academic achievement that signifies that jigsaw teaching method is more effective than existing traditional teacher-centered teaching method. Besides, the experimental group also developed the better understanding of the teaching contents more than the control group. Besides, the experimental group also revealed the retention of the knowledge more than the control group. It is because the control group had difficulties in learning mathematics lessons. Therefore, they could not also retain the knowledge.

Since Jigsaw group students had an opportunity to share knowledge with their peers, they had not the opportunity to learn the lessons effectively but they were also in a good position to share the knowledge their former group members. They key reason in the development of the experimental group students was that they experienced working with their partners, expressed with them the learning difficulties, and also fulfilled their individual responsibilities. Therefore, having acute interaction opportunities helped them learn mathematics skills effectively. These findings are also in line with the previous findings of the studies (Aydin, \& Biyikli, 2017; Baroody, Clements \& Sarama, 2019; Evcim \& İpek, 2013).

As for the attitudes of students towards Jigsaw teaching method, the experimental group students had more positive attitude towards mathematics lessons than the control group students. The reason could be the excitement among the experimental group students since they had the opportunity to learn mathematics lessons for the first time under Jigsaw teaching method. Such an excitement also led them give better performance than the control group. These findings are also supported by the previous findings (Azmin, 2016; Gull \& Shehzad, 2015; Hamadneh, 2017). Additionally, the findings also infer that most learners reported some expressions such as "this style develop learning", "provides cooperation and interaction", "it increases self-confidence,',it lets learners be much active", and "it works us like teaching to learn". Similar kind of views are also reported in the previous studies (Samuel, 2018; Sudrajat, Iasha \& Femayati, 2019; Suresh \& Reddy, 2017).

In conclusion, it is learnt in the current study that the use of Jigsaw teaching method infuses the sense of cooperation in learning among the students. Moreover, it positively impacts students' academic achievement in mathematics classrooms. Besides, the learners also develop the positive attitude towards the mathematics lessons. Such attitudes are likely to benefit the learners to develop keen interest in learning the mathematics. Based on these findings, mathematics curriculum designers, and the instructors are advised to incorporate Jigsaw teaching method in mathematics classrooms. This study also highlights that teacher-centered approach is an obsolete teaching method and less effective in teaching mathematics lessons.

The Jigsaw teaching method can be incorporated effectively following some guidelines. Such as, cooperative learning need to be promoted while teaching mathematics lessons. Prior to the application of Jigsaw teaching method, learners may be informed of the purposes of the said method. In this way, students would be curious for the learning. All the required strategies need to be devised carefully before incorporating the Jigsaw teaching method.Time is the important factor in the Jigsaw teaching method. The instructors are advised to devote ample time to gain significant positive results.

\section{Disclosure statement}

No potential conflict of interest was reported by the authors.

\section{Notes on contributors}

Adil Zamil Abed - Directorate of Anbar Education, Ministry Of Education of Iraq, Iraq.

Sameer Abed Sameer - Directorate of Anbar Education, Ministry Of Education of Iraq, Iraq.

Munadhil Adil Kasim Luna - School of Educational studies, Universiti Sains Malaysia, Malaysia; Directorate of Maysan Education, Ministry of Eduaction of Iraq, Iraq.

Ahamad Tajuddin Othman - School of Educational studies, Universiti Sains Malaysia, Malaysia. 


\section{REFERENCES}

Akers, R. (2017). Social learning and social structure: A general theory of crime and deviance. UK: Routledge. https://doi.org/10.4324/9781315129587

Alzahrani, K. S. (2017). Metacognition and Cooperative Learning in the Mathematics Classroom. International Electronic Journal of Mathematics Education, 12(3), 475-491.

Aydin, A., \& Biyikli, F. (2017). The Effect of Jigsaw Technique on the Students' Laboratory Material Recognition and Usage Skills in General Physics Laboratory-I Course. Universal Journal of Educational Research, 5(7), 1073-1082. https://doi.org/10.13189/ujer.2017.050701

Azmin, N. H. (2016). Effect of the Jigsaw-Based Cooperative Learning Method on Student Performance in the General Certificate of Education Advanced-Level Psychology: An Exploratory Brunei Case Study. International Education Studies, 9(1), 91-106. https://doi.org/10.5539/ies.v9n1p91

Baroody, A. J., Clements, D. H., \& Sarama, J. (2019). Teaching and learning mathematics in early childhood programs. The Wiley Handbook of Early Childhood Care and Education, 329-353. https://doi.org/10.1002/9781119148104.ch15

Capar, G., \& Tarim, K. (2015). Efficacy of the Cooperative Learning Method on Mathematics Achievement and Attitude: A Meta-Analysis Research. Educational Sciences: Theory and Practice, 15(2), 553-559. https://doi.org/10.12738/estp.2015.2.2098

Dunlosky, J., Rawson, K. A., Marsh, E. J., Nathan, M. J., \& Willingham, D. T. (2013). Improving students' learning with effective learning techniques: Promising directions from cognitive and educational psychology. Psychological Science in the Public Interest, 14(1), 4-58. https://doi.org/10.1177/1529i00612453266

Evcim, H., \& İpek, Ö. F. (2013). Effects of jigsaw II on academic achievement in English prep classes. ProcediaSocial and Behavioral Sciences, 70, 1651-1659. https://doi.org/10.1016/j.sbspro.2013.01.236

Fry, H., Ketteridge, S., \& Marshall, S. (Eds.). (2008). A handbook for teaching and learning in higher education: Enhancing academic practice. UK: Routledge. https://doi.org/10.4324/9780203891414

Gray, C., \& Malins, J. (2016). Visualizing research: A guide to the research process in art and design. UK: Routledge. https://doi.org/10.4324/9781315547923

Gull, F., \& Shehzad, S. (2015). Effects of cooperative learning on students' academic achievement. Journal of education and learning (EduLearn), 9(3), 246-255. https://doi.org/10.11591/edulearn.v9i3.2071

Hamadneh, Q. M. S. (2017). The Effect of Using Jigsaw Strategy in Teaching Science on the Acquisition of Scientific Concepts among the Fourth Graders of Bani Kinana Directorate of Education. Journal of Education and Practice, 8(5), 127-134.

Hu, Y. H., Xing, J., \& Tu, L. P. (2018). The Effect of a Problem-oriented Teaching Method on University Mathematics Learning. Eurasia Journal of Mathematics, Science and Technology Education, 14(5), 1695-1703. https://doi.org/10.29333/ejmste/85108

Judd, T., Kennedy, G., \& Cropper, S. (2010). Using wikis for collaborative learning: Assessing collaboration through contribution. Australasian Journal of Educational Technology, 26(3). https://doi.org/10.14742/ajet.1079

Kirillov, A. V., Vinichenko, M. V., Melnichuk, A. V., Melnichuk, Y. A., \& Vinogradova, M. V. (2016). Improvement in the learning environment through gamification of the educational process. International Electronic Journal of Mathematics Education, 11(7), 2071-2085.

Patten, M. L., \& Newhart, M. (2017). Understanding research methods: An overview of the essentials. UK: Routledge. https://doi.org/10.4324/9781315213033

Peris-Ortiz, M., Devece-Carañana, C. A., \& Navarro-Garcia, A. (2018). Organizational learning capability and open innovation. Management Decision, 56(6), 1217-1231. https://oi.org/10.1108/MD-02-2017-0173

Ronfeldt, M., Farmer, S. O., McQueen, K., \& Grissom, J. A. (2015). Teacher collaboration in instructional teams and student achievement. American Educational Research Journal, 52(3), 475-514. https://doi.org/10.1080/15391523.2016.1175856

Samuel, I. R. (2018). Effects of Jigsaw IV, Group Investigation and Reversed Jigsaw Cooperative Instructional Strategies on Basic Science Students' Achievement and Retention. International Journal of Education Research, 6(2), 54-62. 
Serdyukov, P. (2017). Innovation in education: what works, what doesn't, and what to do about it?. Journal of Research in Innovative Teaching \& Learning, 10(1), 4-33. https://doi.org/10.1108/JRIT-10-2016-0007

Skinner, B. F. (2016). The technology of teaching. BF Skinner Foundation.

Sudrajat, A., Iasha, V., \& Femayati, F. (2019). The Influence of the Use of Cooperative Learning Model Jigsaw \& Two Stay Two Stray and the Learning Interest Result on 5th Grade Social Science. ICEAP 2018, 2(2), 28-33. https://doi.org/10.26499/iceap.v2i2.92

Sulisworo, D., Ishafit, I., \& Firdausy, K. (2016). The Development of Mobile Learning Application using Jigsaw Technique. iJIM, 10(3), 11-16. https://doi.org/10.3991/ijim.v10i3.5268

Suresh, C., \& Reddy, V. D. (2017). Effect of jigsaw cooperative learning strategy in promoting insightful learning of junior intermediate students in mathematics. International Journal of Indian Psychology, 4(86), 69-75.

Voyles, E. C., Bailey, S. F., \& Durik, A. M. (2015). New pieces of the jigsaw classroom: increasing accountability to reduce social loafing in student group projects. The new school psychology bulletin, 13(1), 11-20.

Woods, D. M., \& Chen, K. C. (2010). Evaluation techniques for cooperative learning. International Journal of Management \& Information Systems, 14(1), 1-6. https://doi.org/10.19030/ijmis.v14i1.815 